\title{
Raccoon Use of Den Trees and Plant Associations in Western Mesophytic Forests: Tree Attributes and Availability or Landscape Heterogeneity?
}

\author{
Winston P. Smith ${ }^{1,2}$, Keith M. Endres ${ }^{3}$ \\ ${ }^{1}$ United States Department of Agriculture, Forest Service, Southern Research Station, Center for Bottomland Hardwood Research, \\ Stoneville, USA; ${ }^{2}$ Institute of Arctic Biology, University of Alaska-Fairbanks, Fairbanks, USA; ${ }^{3}$ Department of Biology and Center \\ for Management, Utilization, and Protection of Water Resources, Tennessee Technological University, Cookeville, USA. \\ Email: WSmith58@alaska.edu
}

Received July $5^{\text {th }}, 2012$; revised August $13^{\text {th }}, 2012$; accepted August $22^{\text {nd }}, 2012$

\begin{abstract}
We monitored 15 radio-collared raccoons (Procyon lotor) on Davies Island in March 1987-May 1988 to determine the extent to which individual tree attributes or spatial configuration of plant associations (habitat types) across the landscape influenced den use. Of 1091 verified den sites, 428 were in tree cavities. Raccoon occurrence among 4 cover types differed from that expected based on the total area of each across the island and varied across all seasons for all habitat types except Cedar Wood. Preference varied among age and sex groups and across seasons with some groups showing opposite selection for the same cover type in different seasons. Species and diameter-class distributions of selected den trees differed from a random sample of trees across the landscape. Species composition of trees with cavities also differed from the species composition across the study area. American beech (Fagus grandifolia - relative abundance $8.7 \%$ ) was over-represented in the sample of trees with cavities (29.4\%) and trees selected as dens (65\%); diameter at breast height $(\mathrm{dbh})$ of beech den trees averaged $80.0 \mathrm{~cm}$, whereas all beech trees averaged $71.2 \mathrm{~cm}$. For all species combined, mean dbh of den trees was $78.4 \mathrm{~cm}$ as compared to trees with cavities $(67.6 \mathrm{~cm})$, or all trees $(50.4 \mathrm{~cm})$. The relative availability of large, cavity-prone tree species was related to previous logging practices.
\end{abstract}

Keywords: Den Use; Habitat Use; Landscape Heterogeneity; Procyon lotor; Resource Availability; Mesophytic Forest

\section{Introduction}

The raccoon (Procyon lotor, Linnaeus) is common and widespread across North America [1]. Despite having earned a negative reputation in recent years because of its ability to exploit human refuse and live in urban areas [2], raccoons are still viewed as a desirable species in many exurban areas. Raccoon hunting has a long history in the Midwest and southeastern United States; an important recreational activity that also contributed to the local economy [3]. In natural communities, the raccoon is an important predator of nesting waterfowl and other avian species [4]. Its range is restricted largely by proximity to water [5-7]. Some early investigators reported that availability of suitable dens limited raccoon distribution [8-12], but more recent studies have suggested den availability was not a limiting factor [13-17].

Raccoons are opportunistic and use various types of dens. In mixed-mesophytic forests, they used abandoned squirrel nests, tree roosts, and barns in addition to the well-documented rock and ground burrows and tree cavi- ties $[16,18]$. Several studies reported raccoon preferences for various den types, such as rock-outcroppings tree cavities, and ground burrows [1,8,16,18-22]. Reference [18] reported den selection varied among seasons and age and sex groups.

Relative importance of dens in the hierarchy of resources required by raccoons is uncertain, but likely varies across seasons and among habitats and age and sex classes [18]. Whether trees selected as dens represent the best choice (relative to reproductive fitness), or whether den selection is secondary to raccoon preference for other resources (e.g., food) within selected habitat types is unclear. In spatially and temporally patchy environments, resources often do not occur together and thus raccoons must make choices relative to their needs and availability of resources [18]. Moreover, broad-scale disturbance (e.g., logging) can alter the availability and distribution of critical resources [10].

Reference [18] quantified the use of a variety of den types among four age-sex groups of raccoons in a closed 
(i.e., island) population. The purpose of our study was to examine use of tree dens relative to habitat type use by raccoons in an extensively modified and heterogeneous forested landscape. Specific objectives were to 1) quantify features of den trees used by raccoons; 2) determine if selection of den trees was correlated with habitat type use; and 3) determine if variation in den use can be explained by den tree or habitat type availability.

\section{Study Area}

Our study area was Davies Island within Center Hill Reservoir, DeKalb County, Tennessee (Latitude 36 $00^{\circ}$ $45^{\prime} \mathrm{N}$, Longitude $\left.85^{\circ} 42^{\prime \prime} 45^{\prime} \mathrm{W}\right)$. We conducted this study on an island because it facilitated monitoring the movements and behavior of an entire population that had restricted access to a broader landscape [23]. Davies Island is approximately (depending upon water level in Center Hill Reservior) $2.20 \mathrm{~km}$ long (north to south) and 1.85 $\mathrm{km}$ wide and encompassed $271 \mathrm{ha}$. Topography is steep; elevation ranged from $201 \mathrm{~m}$ above mean sea level at the shoreline to $299 \mathrm{~m}$ on the highest ridge.

Seasonal temperature means for the region were as follows: winter (December-February), $5.4^{\circ} \mathrm{C}$; spring (MarchMay), $14.0^{\circ} \mathrm{C}$; summer (June-August), $24.2^{\circ} \mathrm{C}$; and autumn (September-November), $15.0^{\circ} \mathrm{C}$ [24]. Precipitation was heaviest in winter, spring, and early summer, averaging $137.2 \mathrm{~cm}$ annually. Frozen precipitation usually occurred from November to May and averaged $20.8 \mathrm{~cm}$ per year. Typically, snow cover was present for $4-9$ days and the ground freezes to a depth of $10 \mathrm{~cm}$.

Natural vegetation of the area is classified as Western Mesophytic Forest [25], with different species assemblages depending on local site conditions. Reference [26] described 4 upland plant communities on the island: Beech/Maple; Oak/Hickory; Oldfield (Liriodendron-UlmusLiquidambar); and Red-Cedar (=Cedar) woods. The canopy vegetation of Beech/Maple was characterized by the dominance of American beech (Fagus grandifolia), and maple species (Acer saccharum and A. rubrum). Understory vegetation consisted mostly of saplings of canopy dominants, dogwood (Cornus florida), spicebush (Lindera benzoin), and Eunoymous americanus. The herb layer was comprised of dogtooth violet (Erythronium americanum), dwarf crested iris (Iris cristata), phacelia (Phacelia bipinnatifida), false Solomon's seal (Smilacina racemosa), Jack-in-the-Pulpit (Arisema triphyllum), and maiden-hair fern (Adiantum pedatum). Canopy vegetation of Oak/Hickory was dominated by Quercus alba, $Q$. falcate, Q. stellata, Carya glabra, C. ovalis, and C. ovata. Understory vegetation consisted mostly of mountain laurel (Kalmia latifolia), viburnum (Viburnum acerifolium), and huckleberry (Vaccinium). The remaining speciespoor understory was comprised of xeric species, such as spotted wintergreen (Chimaphila maculata), bloodroot (Sanguinaria canadensis), pennywort (Obolaria virginica), christmas fern (Polystichum acrostichoides), and beggar lice (Desmodium nudiflorum). Oldfield canopy was almost completely dominated by the tuliptree (Liriodendron tulipifera), but included successional indicators, such as black locust (Robinia psuedoacacia), honey locust (Gleditsia triacanthos), tree-of-heaven ( $A i$ lanthus altissima), butternut (Juglans cinerea), small elm saplings (Ulmus rubra and U. thomasi), and sumac (Rhus typhina). Understory vegetation consisted primarily of saplings of canopy species and buckbush (Symphoricarpos orbiculatus). Herbaceous species reflected recent disturbance and included thistle (Cirsium altissimum), goldenrod (Solidago spp.), morning glory (Ipomea pandurata), dodder (Cuscuta gronovii), asters (Aster spp.), wild sensitive plant (Cassia nictitans) and ragweed (Ambrosia artemisiifolia). The Cedar Woods canopy was exclusively dominated by red-cedar (Juniperus virginiana), but included a few xeric species, such as Euphorbia corollata, E. dentate, E. mecurialina, Acalypha gracilens, Ruellia ciliosa [26].

Davies Island had been managed by the US Army Corps of Engineers since 1942 when it was acquired as part of the Center Hill Reservoir development. Just prior to its acquisition, the island underwent diameter-limit (i.e., high-grade) harvests, which was a typical forestry practice of non-industrial landowners throughout the region [27]. The extensive, selective logging modified the distribution and composition of natural vegetation communities $[25,26]$. Since that time, the island has been managed primarily for recreation with little vegetative manipulation for either forest or wildlife management.

\section{Materials and Methods}

\subsection{Capture, Handling and Monitoring Animals}

We trapped raccoons using Havahart ${ }^{\circledR}$ (Woodstream Corporation, Lititz, PA, USA) live traps $(76.2 \times 17.8 \times$ $17.8 \mathrm{~cm}$ ) baited with sardines [18,28]. Captured raccoons were immobilized with an intramuscular injection of a mixture $(9: 1)$ of ketamine hydrochloride and acetyl promazine $(0.2 \mathrm{cc} / \mathrm{kg})[29,30]$ and fitted with collar-configuration radio-transmitters (L2B5-H, Telonics, Mesa, AZ, USA). Age of each animal was determined by comparing tooth wear [31] with baculum length and nipple size [32]. Animals $<14$ months of age (age class I) were categorized as juveniles; older animals (age classes II - V) were grouped into a single adult category.

We monitored radio-collared raccoons from March 1987 to May 1988 using a rotating, systematic sampling schedule [18]. At least 3 times weekly, each study animal was located during 1 of 6 circadian activity periods de- 
Tree Attributes and Availability or Landscape Heterogeneity?

fined according to sunrise and sunset: early morning, late morning, early afternoon, late afternoon, early evening, and late evening. Additional observations of each raccoon were recorded in the remaining activity periods so that during each calendar season we recorded a minimum of 24 locations per animal distributed evenly among all activity periods. This procedure was repeated for all seasons throughout the study period. Observations of individuals accompanied by $\geq 1$ additional raccoons were treated as a single, independent, observation. This scheme minimized the potential problem of non-independence of observations in analyses of resource selection [33]. In our paper, tree den was defined as a cavity in the bole or large branch of a tree that provided shelter from inclement weather and predators (including hunting dogs), especially for females nursing young $[10,20]$.

Den locations were verified by walking toward each individual following initial triangulation and identifying den trees or habitat type according to intensity and quality of the radio-transmitter signal [18]. Locations were recorded on individual aerial photographs (scale: 1:5000) and then transferred to a contour map of the island that was digitized from a U.S.G.S. topographic map into ARC/INFO (Environmental Systems Research Institute, Inc., Redlands, CA). Date, time, activity (e.g., denning), and habitat type were recorded.

\subsection{Vegetative Sampling and Statistical Analysis}

We used relative abundance of trees with suitable cavity openings (i.e., appeared large enough to accommodate raccoons) [28] to reflect the availability of tree species among diameter classes. We used a stratified, randomsystematic sampling procedure [34] to establish 103 pointcenter quarter sampling points [35]. That is, proportionally among habitat types we randomly selected the central point in a plot from which additional sampling points were systematically determined [35]. The variance and effect sizes in a preliminary sample indicated we needed $\geq 100$ points [28] to discern differences between available and used trees. We determined frequency, species composition, density and diameter-at-breast height (dbh) for tree stems $>1-m$ circumference and recorded whether there were suitable cavities. Although raccoons may den in smaller trees, our preliminary sample indicated that trees that were $<1-\mathrm{m}$ circumference (i.e., $<32 \mathrm{~cm} \mathrm{dbh}$ ) rarely had visible cavities, or the cavities appeared too small to be used by raccoons. We stratified tree data among 5-cm diameter classes and used KolmogorovSmirnov two-sample tests (NPAR1WAY, SAS/STAT User's Guide) [36] to assess whether the species frequency distribution of trees with cavities or trees selected as dens differed from that available across the island [37]. A similar test for continuous data [37] compared the dbh frequency distribution of cavity trees or den trees with the expected distribution.

We used ARC/INFO to develop an island-wide coverage of plant associations (hereafter habitat types) from recent satellite imagery and aerial photographs (Figure 1). Vegetation sampling and ground-truthing established and verified plant associations (hereafter habitat type) across the landscape, respectively. Proportion of the island encompassed by each habitat type was used to estimate its availability to raccoons. We also used ARC/ INFO to obtain relative abundance of habitat types within seasonal and annual convex polygon home ranges [38] of each study animal. We compared those to corresponding habitat type proportions across the entire island as an assessment of landscape-scale selection of habitat types by individual raccoons. Comparison of relative use $\left(p_{i}\right)$ of each habitat type (i.e., proportion in an individuals' home range) with its corresponding availability, i.e., relative abundance $\left(p_{o}\right)$ across the island, determined habitat type preference [39].

We used multiple contingency table analyses [36] to determine if significant variation in habitat type selection occurred among seasons or among age and sex groups [37]. We used Log-Likelihood Ratio for Contingency Tables (G-statistic) when individual cells had expected values that were $<5$. We used partial chi-square analysis to determine if significant interaction between variables occurred and which categories differed [37]. Selection occurred when raccoon use of a resource differed statistically from what was expected based on the relative abundance (i.e., availability) of each possible category (e.g., tree species); preference refers to use that is greater than expected, whereas avoidance is use that is less than expected. A probability of $\leq 0.05$ was accepted as indicating statistical significance.

Convex polygon estimates of home range can be subject to a sample size bias [40]. However, we estimated the minimum sample size beyond which home range
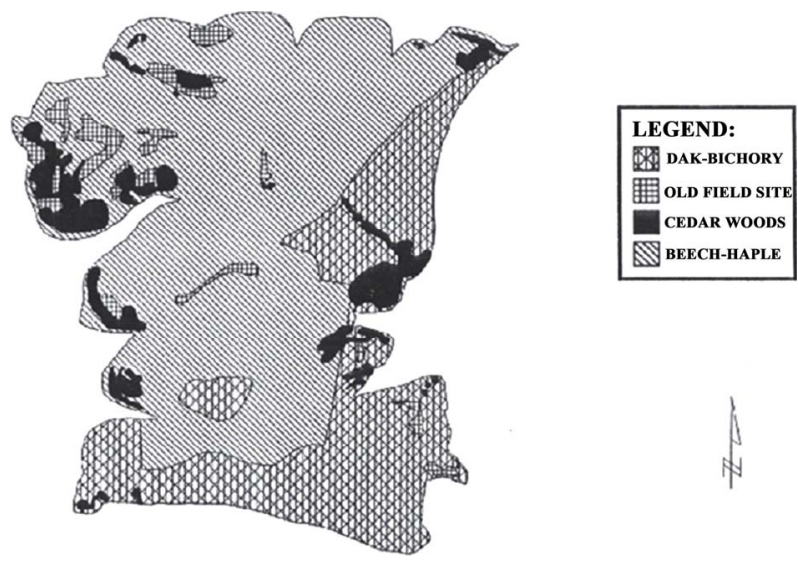

Figure 1. Davies Island, Center Hill Reservoir, USA. 
increased negligibly by plotting number of locations against home-range size [41]. Only raccoons with $\geq 20$ independent observations during a season or $\geq 30$ independent observations over $\geq 9$ months during a year were included in corresponding analyses. Also, we assumed that we had sufficient statistical power to discern differences between habitats used relative to availability [33]. Because we recorded markedly fewer observations in some season $\times \operatorname{sex} \times$ age categories, there may have been a higher likelihood of a Type II error in multiple comparisons of use versus availability. However, there was clear evidence of significant habitat type selection in all but one of the 16 categories we examined; and the category without any evidence of selection had as many or more observations than most of the remaining categories.

Conversely, it is possible that pooling observations (rather than analyzing observations of each animal separately) reduced individual variation and inflated degrees of freedom, a consequence of which might have been over-sensitive statistical analyses resulting in an inflated Type I error [42]. However, we pooled observations only according to age-sex groups, which we expected to behave similarly because of similar life history needs [18]; pooling data across animals is justifiable when they do not differ [42]. Also, because degrees of freedom of our initial Chi-square analysis to compare use with availability was based on number of groups (not number of observations) [37], we believe the Type I error was not inflated. Still, it is possible to obtain spurious conclusions about resource selection if the assumption that individuals within age-sex group behave similarly is untenable. Finally, we assumed that the relative amount of each habitat type across the study area was a realistic estimate of its availability. Reference [43] pointed out that because of the selective nature of many animals, the entire area of each habitat might not be available. Because of topography, geology, and land use, the landscape across our study area was heterogeneous; habitat types and other resources were patchily distributed across the island. Nonetheless, we believe that total area of each habitat type was probably a good estimate of availability because telemetry data indicated that individual raccoons could readily travel to any part of the island [18].

\section{Results}

We captured and fitted 15 raccoons with radio-transmitters during March-September 1987 and monitored each through April 1988: 4 male and 3 female juveniles, and 4 male and 4 female adults. We recorded 1231 daytime and 607 nighttime observations during March 1987-May 1988, from which we obtained 1665 independent observations of habitat type use. Of the daytime locations, 1091 were verified and all but 15 observations were designated as den use by a single raccoon. On 428 (39.2\%) occasions, raccoons selected tree cavities for denning; remaining den sites were either ground burrows or grottos within rock out-croppings.

\subsection{Habitat Availability and Use}

\subsubsection{Habitat Selection across the Landscape}

Beech/Maple forest occurred throughout most of the study area and was the most abundant habitat type, representing about $59.2 \%$ (160.4 ha) of the island (Figure 1). Oak/Hickory forest was the next most abundant plant community, occupying 78.9 ha (29.1\%), but mostly restricted to the eastern and southern edge of the island. Cedar Woods (7.7\%) and Oldfield (4.0\%) communities comprised the remaining 31.7 ha; Oldfield was limited $(>75 \%$ of the total) to the northwest quarter of the island, whereas Cedar Woods occurred along the east-and westcentral edges of the study area (Figure 1).

Mean proportion of each habitat type included in seasonal home ranges of radio-collared raccoons (Table 1) differed (spring $-\chi^{2}=676, d f=3, P<0.001$; summer $-\chi^{2}$ $=225, d f=3, P<0.001$; autumn $-\chi^{2}=552, d f=3, P<$ 0.001 ; winter $-\chi^{2}=808, d f=3, P<0.001$ ) from what was expected based on the total area of each habitat type across the study area. Annual averages were as follows: Beech/Maple forest, 70.5\%; Oak/Hickory forest, $13.1 \%$; Cedar Woods, $10.0 \%$; and Oldfield, $6.4 \%$. Invariably, Beech/Maple forest was a greater percentage and Oak/ Hickory a smaller proportion of seasonal home ranges than expected from their representation across the island (Table 1). Remaining habitat types were less predictable, varying both among seasons and according to the age and sex of individuals. Mean proportion of habitat types within seasonal home ranges did not vary among seasons $\left(\chi^{2}=8, d f=12, P>0.50\right)$.

\subsubsection{Habitat Use within Home Ranges}

According to radio-telemetry locations within home ranges, raccoon use of habitat types was not independent of season $\left(\chi^{2}=113, d f=9, P<0.0001\right)$ or age and sex group $\left(\chi^{2}=373, d f=9, P<0.0001\right)$. Generally, habitattype use differed $(P \leq 0.05)$ among all seasons for all habitat types; an exception was Cedar Woods, in which there was proportional use $\left(\chi^{2}<7.815, d f=3, P>0.05\right)$ throughout the year (Table 1). The greatest departure from uniform use among seasons occurred during summer for all habitat types except Cedar Woods, use of which deviated during autumn. Raccoons used Beech/ Maple and Oak/Hickory more during spring and less during summer than expected (Table 2). In contrast, Oldfield received greater use during summer and less use during spring than expected. 
Tree Attributes and Availability or Landscape Heterogeneity?

Table 1. Average proportions of habitat types in seasonal home ranges of raccoons (Procyon lotor) $(\mathrm{n}=15)$ and mean percentage of radio-telemetry locations recorded within each habitat type, Davies Island, Center Hill Reservoir, Tennessee, USA, March 1987-May 1988. (Range is given in parentheses).

\begin{tabular}{|c|c|c|c|c|}
\hline Type of Observation & Beech-Maple (\%) & Oak-Hickory (\%) & Cedar Woods (\%) & Oldfield (\%) \\
\hline & \multicolumn{4}{|c|}{ Spring } \\
\hline Home Range Composition & $77.1(66.1-96.7)$ & $10.6(0.0-28.5)$ & $5.4(0.1-14.9)$ & $6.8(0.0-18.6)$ \\
\hline \multirow[t]{2}{*}{ Telemetry Locations } & $65.1(60.6-70.3)$ & $10.5(0.0-16.2)$ & $12.6(4.3-19.0)$ & $11.8(0.0-30.3)$ \\
\hline & \multicolumn{4}{|c|}{ Summer } \\
\hline Home Range Composition & $64.4(38.4-79.4)$ & $16.2(0.0-51.2)$ & $11.7(3.1-22.8)$ & $7.9(0.1-21.4)$ \\
\hline \multirow[t]{2}{*}{ Telemetry Locations } & $37.2(23.8-55.0)$ & $24.9(0.0-39.1)$ & $11.2(6.2-16.2)$ & $26.7(10.8-53.6)$ \\
\hline & \multicolumn{4}{|c|}{ Autumn } \\
\hline Home Range Composition & $75.0(58.9-84.7)$ & $11.9(0.0-32.0)$ & $6.8(3.3-21.3)$ & $6.3(0.1-15.9)$ \\
\hline \multirow[t]{2}{*}{ Telemetry Locations } & $55.8(41.5-80.9)$ & $17.8(0.0-44.6)$ & $6.6(3.1-8.0)$ & $19.8(1.4-47.1)$ \\
\hline & \multicolumn{4}{|c|}{ Winter } \\
\hline Home Range Composition & $77.9(56.2-99.9)$ & $7.8(0.0-36.8)$ & $8.5(0.0-32.8)$ & $6.1(0.1-21.4)$ \\
\hline Telemetry Locations & $62.7(47.2-77.7)$ & $14.2(0.0-36.5)$ & $13.2(1.9-30.1)$ & $9.9(0.0-22.3)$ \\
\hline
\end{tabular}

Table 2. Seasonal occurrence of juvenile and adult female and male raccoons (Procyon lotor) among habitat types March 1987-May 1988; $n$ = number of locations and used to compute family confidence intervals [39].

\begin{tabular}{|c|c|c|c|c|c|c|c|}
\hline \multicolumn{8}{|c|}{ Spring $(n=456)$} \\
\hline \multirow{3}{*}{ Habitat types } & \multirow{3}{*}{$\begin{array}{l}\text { Proportion of all } \\
\text { habitat types }{ }^{\mathrm{a}}\left(p_{o}\right)\end{array}$} & \multicolumn{6}{|c|}{ Males $(n=159)$} \\
\hline & & \multicolumn{3}{|c|}{ Juveniles $(n=42)$} & \multicolumn{3}{|c|}{ Adults $(\mathrm{n}=117)$} \\
\hline & & $\begin{array}{c}\text { Proportion } \\
\text { observed }\left(p_{i}\right)\end{array}$ & $\begin{array}{l}95 \% \text { family confidence } \\
\text { interval for } p_{i}^{\mathrm{b}}\end{array}$ & Index of use $e^{c}$ & $\begin{array}{c}\text { Proportion } \\
\text { observed }\left(p_{i}\right)\end{array}$ & $\begin{array}{l}95 \% \text { family confidence } \\
\text { interval for } p_{i}{ }^{\mathrm{b}}\end{array}$ & Index of use \\
\hline Beech/Maple & 0.592 & 0.667 & $0.486-0.848$ & o & 0.624 & $0.512-0.736$ & o \\
\hline Oak/Hickory & 0.291 & 0.143 & $0.008-0.278$ & o & 0.162 & $0.077-0.247$ & - \\
\hline Cedar Woods & 0.077 & 0.190 & $0.039-0.341$ & $\mathrm{o}$ & 0.043 & $0.000-0.090$ & $\mathrm{o}$ \\
\hline Oldfield & 0.040 & 0.000 & $0.000-0.000$ & - & 0.171 & $0.084-0.254$ & + \\
\hline \multirow{3}{*}{ Habitat types } & & \multicolumn{6}{|c|}{ Females $(n=297)$} \\
\hline & Proportion of all & \multicolumn{3}{|c|}{ Juveniles $(\mathrm{n}=132)$} & \multicolumn{2}{|r|}{ Adults $(\mathrm{n}=165)$} & \\
\hline & & $\begin{array}{l}\text { Proportion } \\
\text { observed }\left(p_{i}\right)\end{array}$ & $\begin{array}{l}95 \% \text { family confidence } \\
\text { interval for } p_{i}^{\mathrm{b}}\end{array}$ & Index of use ${ }^{c}$ & $\begin{array}{c}\text { Proportion } \\
\text { observed }\left(p_{i}\right)\end{array}$ & $\begin{array}{l}95 \% \text { family confidence } \\
\text { interval for } p_{i}^{\mathrm{b}}\end{array}$ & Index of use ${ }^{\mathrm{c}}$ \\
\hline Beech/Maple & 0.592 & 0.606 & $0.500-0.712$ & o & 0.703 & $0.614-0.792$ & + \\
\hline Oak/Hickory & 0.291 & 0.000 & $0.000-0.000$ & - & 0.115 & $0.053-0.177$ & - \\
\hline Cedar Woods & 0.077 & 0.091 & $0.028-0.154$ & o & 0.182 & $0.107-0.257$ & + \\
\hline
\end{tabular}




\begin{tabular}{|c|c|c|c|c|c|c|c|}
\hline \multicolumn{8}{|c|}{ Summer $(n=426)$} \\
\hline \multirow{3}{*}{ Habitat types } & \multirow{3}{*}{$\begin{array}{l}\text { Proportion of all } \\
\text { habitat types }{ }^{\mathrm{a}}\left(p_{o}\right)\end{array}$} & \multicolumn{6}{|c|}{ Males $(n=194)$} \\
\hline & & \multicolumn{3}{|c|}{ Juveniles $(\mathrm{n}=130)$} & \multicolumn{3}{|c|}{ Adults $(\mathrm{n}=64)$} \\
\hline & & $\begin{array}{c}\text { Proportion } \\
\text { observed }\left(p_{i}\right)\end{array}$ & $\begin{array}{l}95 \% \text { family confidence } \\
\text { interval for } p_{i} \text { b }\end{array}$ & Index of use $e^{c}$ & $\begin{array}{c}\text { Proportion } \\
\text { observed }\left(p_{i}\right)\end{array}$ & $\begin{array}{l}95 \% \text { family confidence } \\
\text { interval for } p_{i}^{\mathrm{b}}\end{array}$ & Index of use ${ }^{c}$ \\
\hline Beech/Maple & 0.592 & 0.238 & $0.145-0.331$ & - & 0.359 & $0.209-0.509$ & - \\
\hline Oak/Hickory & 0.291 & 0.362 & $0.302-0.422$ & + & 0.391 & $0.239-0.543$ & o \\
\hline Cedar Woods & 0.077 & 0.162 & $0.081-0.243$ & + & 0.062 & $0.000-0.137$ & o \\
\hline Oldfield & 0.040 & 0.238 & $0.145-0.331$ & + & 0.188 & $0.066-0.310$ & + \\
\hline \multirow{3}{*}{ Habitat types } & \multirow{3}{*}{$\begin{array}{l}\text { Proportion of all } \\
\text { habitat types }^{\mathrm{a}}\left(p_{o}\right)\end{array}$} & \multicolumn{6}{|c|}{ Females $(n=232)$} \\
\hline & & \multicolumn{3}{|c|}{ Juveniles $(\mathrm{n}=112)$} & \multicolumn{3}{|c|}{ Adults $(n=120)$} \\
\hline & & $\begin{array}{c}\text { Proportion } \\
\text { observed }\left(p_{i}\right)\end{array}$ & $\begin{array}{l}\text { 95\% family confidence } \\
\text { interval for } p_{i}^{\text {b }}\end{array}$ & Index of use $e^{c}$ & $\begin{array}{l}\text { Proportion } \\
\text { observed }\left(p_{i}\right)\end{array}$ & $\begin{array}{l}95 \% \text { family confidence } \\
\text { interval for } p_{i}^{\mathrm{b}}\end{array}$ & Index of use ${ }^{c}$ \\
\hline Beech/Maple & 0.592 & 0.339 & $0.227-0.451$ & - & 0.550 & $0.437-0.663$ & o \\
\hline Oak/Hickory & 0.291 & 0.000 & $0.000-0.000$ & - & 0.242 & $0.144-0.340$ & o \\
\hline Cedar Woods & 0.077 & 0.125 & $0.047-0.023$ & o & 0.100 & $0.032-0.168$ & o \\
\hline Oldfield & 0.040 & 0.536 & $0.418-0.654$ & + & 0.108 & $0.037-0.179$ & o \\
\hline \multicolumn{8}{|c|}{ Autumn $(n=443)$} \\
\hline \multirow{2}{*}{ Habitat types } & Proportion of all & & Juveniles $(\mathrm{n}=104)$ & & & Adults $(n=65)$ & \\
\hline & กับช & $\begin{array}{c}\text { Proportion } \\
\text { observed }\left(p_{i}\right)\end{array}$ & $\begin{array}{l}95 \% \text { family confidence } \\
\text { interval for } p_{i}^{\mathrm{b}}\end{array}$ & Index of use $e^{c}$ & $\begin{array}{l}\text { Proportion } \\
\text { observed }\left(p_{i}\right)\end{array}$ & $\begin{array}{l}95 \% \text { family confidence } \\
\text { interval for } p_{i}^{\mathrm{b}}\end{array}$ & Index of use ${ }^{c}$ \\
\hline Beech/Maple & 0.592 & 0.558 & $0.436-0.680$ & o & 0.415 & $0.262-0.568$ & - \\
\hline Oak/Hickory & 0.291 & 0.164 & $0.073-0.255$ & - & 0.446 & $0.292-0.600$ & + \\
\hline Cedar Woods & 0.077 & 0.077 & $0.012-0.142$ & $\mathrm{o}$ & 0.031 & $0.000-0.085$ & $\mathrm{o}$ \\
\hline Oldfield & 0.040 & 0.201 & $0.103-0.299$ & + & 0.108 & $0.012-0.204$ & o \\
\hline \multirow{3}{*}{ Habitat types } & & \multicolumn{6}{|c|}{ Females $(n=274)$} \\
\hline & $\begin{array}{l}\text { Proportion of all } \\
\text { habitat types }{ }^{\mathrm{a}}\left(p_{o}\right)\end{array}$ & & Juveniles $(\mathrm{n}=138)$ & & & Adults $(\mathrm{n}=136)$ & \\
\hline & & $\begin{array}{c}\text { Proportion } \\
\text { observed }\left(p_{i}\right)\end{array}$ & $\begin{array}{l}95 \% \text { family confidence } \\
\text { interval for } p_{i}^{\mathrm{b}}\end{array}$ & Index of use $e^{c}$ & $\begin{array}{l}\text { Proportion } \\
\text { observed }\left(p_{i}\right)\end{array}$ & $\begin{array}{l}95 \% \text { family confidence } \\
\text { interval for } p_{i}^{\mathrm{b}}\end{array}$ & Index of use \\
\hline Beech/Maple & 0.592 & 0.449 & $0.343-0.555$ & - & 0.809 & $0.725-0.893$ & + \\
\hline Oak/Hickory & 0.291 & 0.000 & $0.000-0.000$ & - & 0.103 & $0.038-0.168$ & - \\
\hline Cedar Woods & 0.077 & 0.080 & $0.022-0.138$ & o & 0.074 & $0.018-0.130$ & o \\
\hline Oldfield & 0.040 & 0.471 & $0.356-0.577$ & + & 0.014 & $0.000-0.039$ & - \\
\hline
\end{tabular}


Winter $(\mathrm{n}=340)$

Males $(\mathrm{n}=134)$

\begin{tabular}{|c|c|c|c|c|c|c|c|}
\hline \multirow{2}{*}{ Habitat types } & \multirow{2}{*}{$\begin{array}{l}\text { Proportion of all } \\
\text { habitat types }{ }^{\mathrm{a}}\left(p_{o}\right)\end{array}$} & \multicolumn{3}{|c|}{ Juveniles $(\mathrm{n}=71)$} & \multicolumn{3}{|c|}{ Adults $(\mathrm{n}=63)$} \\
\hline & & $\begin{array}{l}\text { Proportion } \\
\text { observed }\left(p_{i}\right)\end{array}$ & $\begin{array}{l}95 \% \text { family confidence } \\
\text { interval for } p_{i}^{\mathrm{b}}\end{array}$ & Index of use ${ }^{c}$ & $\begin{array}{l}\text { Proportion } \\
\text { observed }\left(p_{i}\right)\end{array}$ & $\begin{array}{l}95 \% \text { family confidence } \\
\text { interval for } p_{i}^{\mathrm{b}}\end{array}$ & Index of use \\
\hline Beech/Maple & 0.592 & 0.746 & $0.617-0.875$ & + & 0.508 & $0.351-0.665$ & o \\
\hline Oak/Hickory & 0.291 & 0.000 & $0.000-0.000$ & - & 0.365 & $0.214-0.516$ & o \\
\hline Cedar Woods & 0.077 & 0.099 & $0.011-0.187$ & o & 0.111 & $0.012-0.210$ & o \\
\hline Oldfield & 0.040 & 0.155 & $0.048-0.262$ & + & 0.016 & $0.000-0.055$ & o \\
\hline \multirow{3}{*}{ Habitat types } & & \multicolumn{6}{|c|}{ Females $(n=206)$} \\
\hline & $\begin{array}{l}\text { Proportion of all } \\
\text { habitat types }{ }^{\mathrm{a}}\left(p_{o}\right)\end{array}$ & & Juveniles $(\mathrm{n}=103)$ & & & Adults $(\mathrm{n}=103)$ & \\
\hline & & $\begin{array}{l}\text { Proportion } \\
\text { observed }\left(p_{i}\right)\end{array}$ & $\begin{array}{l}95 \% \text { family confidence } \\
\text { interval for } p_{i}^{\mathrm{b}}\end{array}$ & Index of use ${ }^{c}$ & $\begin{array}{l}\text { Proportion } \\
\text { observed }\left(p_{i}\right)\end{array}$ & $\begin{array}{l}95 \% \text { family confidence } \\
\text { interval for } p_{i}^{\mathrm{b}}\end{array}$ & Index of use \\
\hline Beech/Maple & 0.592 & 0.472 & $0.349-0.595$ & o & 0.777 & $0.675-0.879$ & + \\
\hline Oak/Hickory & 0.291 & 0.000 & $0.000-0.000$ & - & 0.204 & $0.105-0.303$ & o \\
\hline Cedar Woods & 0.077 & 0.301 & $0.188-0.414$ & + & 0.019 & $0.000-0.053$ & - \\
\hline Oldfield & 0.040 & 0.223 & $0.121-0.325$ & + & 0.000 & $0.000-0.000$ & - \\
\hline
\end{tabular}

${ }^{\mathrm{a}}$ Proportions of all den types represent availability and expected raccoon use of each corresponding den type; ${ }^{\mathrm{b}}$ Individual den-type proportion estimates represent $98.5 \%(\alpha / 2 \mathrm{k})$ confidence intervals [39]; ${ }^{\mathrm{c}}+=$ preferred, $-=$ avoided, $\mathrm{o}=$ used in proportion to availability.

\subsubsection{Habitat Use Relative to Availability}

Overall, raccoon occurrence within habitat types differed $\left(\chi^{2}=2,379, d f=27, P<0.0001\right)$ from that expected according to the relative abundance of each across the island (Table 2). Two exceptions were male and female adults during winter and summer, respectively. Moreover, use of habitat types relative to availability varied according to individual age and sex and among seasons. Adult females avoided $(P<0.05)$ Oldfield during all seasons, except summer, when it was used proportionally. In contrast, juvenile females preferred Oldfield throughout the year. In addition, there were circumstances in which the same individuals exhibited diametrically opposite selection for the same habitat type in different seasons. Juvenile males used Beech/Maple forest much less than expected during summer, but preferred $(P<0.05)$ this habitat type during winter. A similar pattern occurred with juvenile male use of Oak/Hickory forest during autumn and summer, respectively (Table 2).

Beech/Maple forest (the most abundant habitat type) was mostly avoided or used proportionally. Adult females, however, frequently used Beech/Maple through out the year with strong preferences during spring and autumn (Table 2). Conversely, Oldfield (the least abundant habitat type) received greater use than expected during at least 2 seasons by all raccoons. During summer, Oldfield was preferred by all raccoons except adult females, whose use approached statistical significance (Table 2). Oak/Hickory forest was preferred by juvenile and adult males during summer and autumn, respectively, but mostly avoided by females, receiving only proportional use by adult females during summer and winter. With few exceptions, Cedar Woods was used proportionally throughout the year by all raccoons.

\subsection{Den Tree Availability and Use}

We assessed availability of cavity openings in 412 trees representing 28 species. Species for which there was only a single observation $(n=7)$ were pooled into a single category entitled "Other" (Table 3). A total of 41 trees distributed among 12 species had $\geq 1$ visible cavity opening large enough to accommodate raccoons. The sample of trees selected as dens consisted of 109 individual trees and 10 species (Table 3). Mean dbh of available trees 
ranged from 36.9 to $71.2 \mathrm{~cm}$ and averaged $50.4 \mathrm{~cm}$ (Table 3). Overall, trees with cavities averaged $67.6 \mathrm{~cm}$ (range 34.7 - 101.9), whereas den trees averaged $78.4 \mathrm{~cm}$ (range $=39.1-109.2$ ). The density of trees with $>1-\mathrm{m}$ circumference was $77.6 \mathrm{stems} / \mathrm{ha}$; trees with visible cavities averaged 8.1 stems $/$ ha.

\subsubsection{Species Composition of Available and Selected Den Trees}

Relative frequency of each species among trees with cavities differed ( $\mathrm{D}=0.773, P=0.0001)$ from that predicted by each species representation among trees with $>1-m$ circumference across the island (Figures 2(a) and (b)). Also, species composition of trees selected as dens (Figure 2(c)) differed ( $\mathrm{D}=0.773, P=0.0001)$ from the forest stand composition (Figure 2(a)), but did not differ
$(\mathrm{D}=0.227, P=0.621)$ from the sample of trees with cavities (Figure 2(b)).

Most cavities (67\%) occurred among 3 species (Figure 2(b)). American beech was over-represented in the distribution of trees with cavities (34.9\%; Figure 2(b)) and in the sample of trees selected as dens (65\%; Figure 2(c)) as compared to its representation across the island (8.7\%; Figure 2(a)). In addition, sugar maple (Acer saccharum) and bitternut hickory (Carya cordiformis) comprised a greater proportion of trees with cavities than expected. Among den trees, yellow poplar (Liriodendron tulipfera) represented the second-most frequently selected species, but it represented $34 \%$ of available trees across the island (Figure 2(a)). White oak (Quercus $a l b a$ ), however, was selected $4 \times$ more often than expected.

Table 3. For stems > l-m circumference, frequency, and mean diameter-at-breast height (cm) of available trees, trees with cavities, and trees used by raccoons (Procyon lotor) for denning on Davies Island, Center Hill Reservoir, Tennessee, March 1987-May 1988. ( $n$ = sample size; $s$ = standard deviation).

\begin{tabular}{|c|c|c|c|c|c|c|c|c|c|}
\hline \multirow{2}{*}{ eciesSp } & \multicolumn{3}{|c|}{ Available } & \multicolumn{3}{|c|}{ Trees with Cavities } & \multicolumn{3}{|c|}{ Den Trees } \\
\hline & Mean & $\mathrm{s}$ & $\mathrm{n}$ & Mean & $\mathrm{s}$ & $\mathrm{n}$ & Mean & $\mathrm{s}$ & $\mathrm{n}$ \\
\hline Liriodendron tulipifera & 45.6 & 0.408 & 140 & 58.9 & 0.661 & 3 & 65.0 & 13.053 & 13 \\
\hline Fagus grandifolia & 71.2 & 0.554 & 36 & 79.3 & 0.549 & 15 & 80.0 & 17.336 & 71 \\
\hline Quercus prinus & 49.9 & 0.529 & 31 & 101.9 & 0 & 1 & 73.7 & 16.343 & 5 \\
\hline Acer saccharum & 50.6 & 0.458 & 30 & 57.6 & 0.628 & 8 & - & - & - \\
\hline Quercus rubra & 59.7 & 0.728 & 26 & 69.4 & 0.481 & 2 & 109.2 & 0 & 1 \\
\hline Carya cordiformis & 53.3 & 0.608 & 23 & 62.0 & 0.681 & 6 & - & - & - \\
\hline Carya ovata & 46.6 & 0.360 & 18 & 50.8 & 0 & 1 & 50.8 & 0 & 1 \\
\hline Fraxinus americana & 45.8 & 0.315 & 18 & 74.2 & 0 & 1 & 95.5 & 0 & 1 \\
\hline Liquidambar styraciflua & 42.0 & 0.268 & 16 & - & - & - & 39.1 & 0 & 1 \\
\hline Quercus alba & 53.0 & 0.467 & 12 & - & - & - & 85.1 & 17.400 & 13 \\
\hline Quercus muehlenbergii & 43.4 & 0.235 & 10 & 56.0 & 0 & 1 & - & - & - \\
\hline Acer rubra & 54.1 & 0.731 & 7 & 95.5 & 0 & 1 & - & - & - \\
\hline Aesculus octandra & 38.9 & 0.235 & 7 & 36.0 & 0 & 1 & - & - & - \\
\hline Quercus coccinea & 57.1 & 0.644 & 7 & - & - & - & - & - & - \\
\hline Juniperus virginiana & 56.8 & 0.187 & 6 & - & - & - & - & - & - \\
\hline Ailanthus altissima & 41.2 & 0.248 & 6 & 34.7 & 0 & 1 & - & - & - \\
\hline Platanus occidentalis & 54.6 & 0.577 & 3 & - & - & - & 83.8 & 0 & 2 \\
\hline Prunus serotina & 42.5 & 0.346 & 3 & - & - & - & - & - & - \\
\hline Carya tomentosa & 78.8 & 0.247 & 2 & - & - & - & - & - & - \\
\hline Diospyros virginiana & 36.9 & 0.212 & 2 & - & - & - & - & - & - \\
\hline Tilia heterophylla & 52.5 & 0.240 & 2 & - & - & - & - & - & - \\
\hline Other & 41.5 & 0.226 & 7 & $37.2^{\mathrm{a}}$ & 0 & 1 & $87.6^{\mathrm{b}}$ & 0 & 1 \\
\hline Total & & & 412 & & & 41 & & & 109 \\
\hline
\end{tabular}

${ }^{\mathrm{a}}$ Quercus ilicifolia $;{ }^{\mathrm{b}}$ Ulmus americana. 

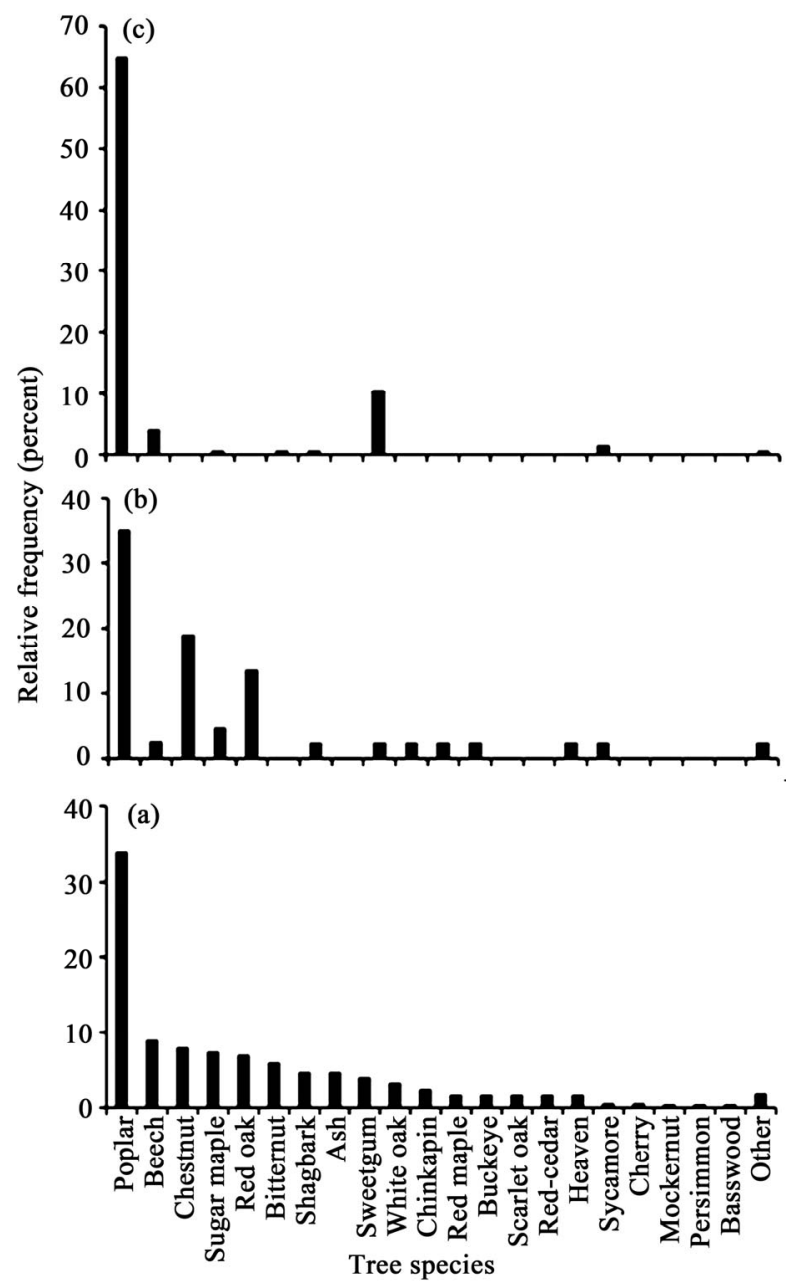

Figure 2. Relative frequency distribution of trees among species that comprised potential (stems $>1$-m circumference) cavity trees (a); trees with cavities large enough to accommodate raccoons (b); and trees selected as dens by raccoons (c); Davies Island, Center Hill Reservoir, Tennessee, USA, March 1987-May 1988.

\subsubsection{Diameter Distribution of Available and Used Den Trees}

The relative frequency of trees with cavities $(\mathrm{D}=0.545$, $P=0.003)$ and den trees $(\mathrm{D}=0.489, P=0.01)$ among 5 -cm diameter classes departed from the expected forest stand composition (Figure 3). The diameter distribution of den trees, however, did not differ from available trees with cavities $(\mathrm{D}=0.364, P=0.109)$. Most $(72.4 \%)$ available trees were in diameter classes ranging from 30.0 to $60 \mathrm{~cm}$ (Figure 3(a)), whereas $72.5 \%$ of den trees were in diameter classes ranging from $65 \mathrm{~cm}$ to $100 \mathrm{~cm}$ (Figure 3(c)). Similarly, most (51.2\%) available trees with cavities (Figure 3(b)) were in diameter classes between $60 \mathrm{~cm}$ and $90 \mathrm{~cm}$. For all species combined, mean dbh of trees differed among categories $(\mathrm{F}=8.89, d f=2$, $562, P<0.0001$; one-way ANOVA) [37]. Potential trees

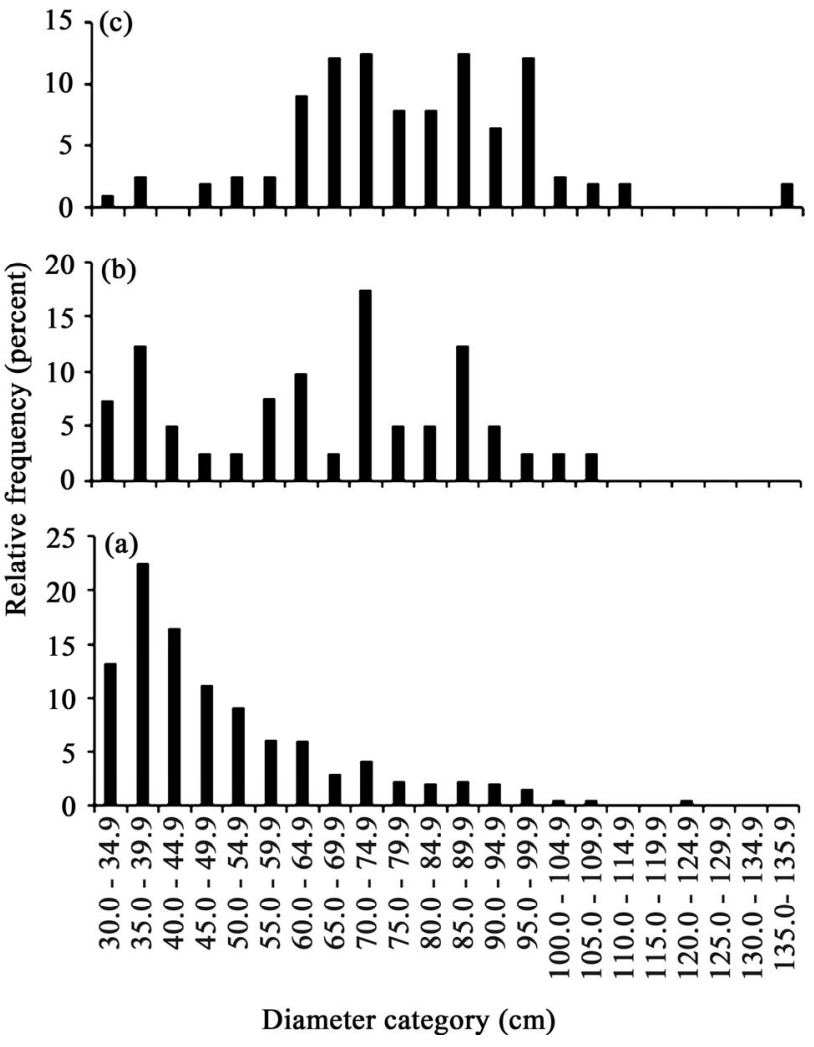

Figure 3. Relative frequency distribution of trees among diameter classes that comprised potential (stems $>1$-m circumference) cavity trees (a); trees with cavities that were large enough to accommodate raccoons (b); and trees selected as dens by raccoons (c); Davies Island, Center Hill Reservoir, Tennessee, USA, March 1987-May 1988.

(mean $=50.4 \mathrm{~cm})$ were smaller $(q=7.41, d f=562, \mathrm{k}=3$, $P<0.001$, Tukey test) [37] than den trees (mean $=78.4$ $\mathrm{cm})$ and smaller $(q=4.99, d f=562, k=3, P<0.005)$ than trees with cavities (mean $=67.6 \mathrm{~cm})$; den trees did not differ from trees with cavities $(q=2.66, d f=562, \mathrm{k}=$ $3, P>0.10)$.

\section{Discussion}

\subsection{Habitat Selection}

Habitat-type selection was estimated at two spatial scales: the proportion of habitat types in individual home ranges likely reflected choices made relative to what was available across the entire island; whereas, radio-telemetry locations represented more fine-scale habitat selection within home ranges [43]. The overall similarity between spatial scales in relative use of habitat types among seasons suggests that attractive micro- and macro-habitat features were not spatially segregated [44]. Notable exceptions were Beech/Maple forest and Oldfield during summer when each comprised a larger and smaller portion, respectively, of raccoon home ranges than corre- 
sponding estimates of habitat-type use obtained from telemetry locations. However, raccoon home ranges included Beech/Maple sites that were adjacent to Oldfield, which were visited frequently during summer.

Raccoons in this study showed substantial variation in use of habitat types. Seasonal variation was likely associated with temporal and spatial heterogeneity of resources [45]. Raccoons on the island exhibited little home range fidelity among seasons [28]; frequently, movements were directly associated with seasonal and patchy food resources such as Rubus sp., Vitis sp, and Diospyros sp. [18]. A similar shift in center of activity relative to availability of ephemeral food resources has been reported by several investigators [1,46-48]. Furthermore, the response of individuals to patchy resource distribution varies significantly among raccoons of different age and sex $[18,49]$.

In this study, resources varied both spatially and temporally. Oldfield and Cedar Woods did not occur on a large portion of the island. Also, distributions of potential cavity trees were not uniform throughout the island. Bitternut hickory, in particular, occurred less in the southern portion and was more common in the central portion of the island. Select food resources such as Rubus sp. were available solely at certain times of the year and occurred mostly in Oldfield. Raccoons responded to ephemeral resources by concentrating activity within those areas. Reference [44] reported similar behavior, noting that raspberries frequently influenced fine-scale raccoon activities and use of associated or adjacent habitats. In our study, the preference by essentially all raccoons for Oldfield throughout the summer was likely related to an abundance of blackberries [18].

Because raccoons often establish den sites near concentrated food sources [18,22,46,49], frequent activity surrounding blackberry thickets in this study likely had implications for other resources. Certain habitat types or other resources likely were used more or less depending upon juxtaposition to Oldfield. It was not uncommon to observe several raccoons use less preferred den trees (e.g., sweetgum, or smaller oaks) while using blackberry thickets in the same Oldfield patch. Reference [44] reported that raccoon use of certain microhabitat features or fine-scale resources was significantly influenced by the broader landscape context. They noted that raccoons were more likely to use suboptimal habitats in portions of landscapes with large amounts of other preferred resources.

Raccoons in this study substantially reduced their use of Beech/Maple during summer; only adult females did not avoid this habitat type. There were Beech/Maple stands immediately adjacent to most of the Oldfield patches on the island. To most raccoons, a change in use of Beech/Maple during summer likely was a conesquence of their increased use of Oldfield; that is, raccoons likely were responding to the positive value of Rubus thickets. To females with young, however, the coincidence of Oldfield and Beech/Maple likely represented an especially attractive condition. Cavities in large American beech trees probably were an equally valuable resource to females with young [10] that facilitated access to an essential, temporary food resource without compromising the quality of natal dens. This conclusion is supported by several lines of evidence. First, females with young mostly used American beech for denning during this period, whereas other raccoons used ground burrow dens in the immediate vicinity of Rubus thickets [18]. Second, summer home ranges of adult females were comprised largely of Beech/Maple stands near Oldfield, the latter of which experienced as much use as the former yet represented a much smaller portion of the home range. Third, adult females used Beech/Maple forest more often than males during summer. Fourth, Oldfield and adjacent Oak/Hickory stands on the southwestern portion of the island received little use by females during this period. Finally, excluding adult females, Oak/Hickory stands were apparently attractive to most raccoons during summer. Indeed, juvenile males preferred this habitat type, spending most of the summer in Oak/Hickory forest.

Some of the significant variation in this study cannot readily be explained as it does not seem consistent with our understanding of raccoon behavior. Oak/Hickory occurred over nearly $30 \%$ of the island, yet received less than $16 \%$ use overall. This may in part be due to its availability in the home ranges of individuals that selected other portions of the landscape. Regardless, raccoons were avoiding either Oak/Hickory or the eastern and southern edge of the island. Some raccoons (e.g., adult males) preferred Oak/Hickory during some seasons; others (e.g., juvenile females) were never recorded in Oak/Hickory. We expected more general use of this habitat type, especially during autumn when fruits and nuts typically are an abundant food resource. Mean density of hard and soft fruit-bearing trees $>32 \mathrm{~cm}$ dbh was 32 stems/ha. Hickories and oaks comprised 76\% (24 stems/ha) of the mast-producing trees with red oak (Quercus rubra), white oak (Q. alba) and shagbark hickory (Carya ovata) averaging 4.9, 2.3 and 3.4 stems/ha, respectively.

Reference [50] recommended a minimum of 56 stems/ ha of oaks and hickories $>25 \mathrm{~cm}$ dbh to meet the needs of squirrels in mixed hardwood forests. Although raccoons probably do not depend as heavily on hard mast as tree squirrels (Sciuridae), it appears that the abundance of desirable mast-producing trees on Davies Island was appreciably less than would be considered minimally ade- 
Tree Attributes and Availability or Landscape Heterogeneity?

quate for supporting some arboreal species [50]. Unfortunately, we did not collect any data on acorn or other fruit production during this study. A study by [51], however, suggests that acorn production on Davies Island should have been adequate. Mean diameter of red oaks and white oaks on Davies Island (Table 3) approached bole sizes of oak trees that typically produce most often and yield the greatest quantity of acorns [51].

\subsection{Den Tree Selection}

Trees with cavities clearly were larger and biased toward just a few species. Similar results were reported for an Oak/Hickory forest in Missouri [52] and among several forest types in South Carolina and Florida [53]. Raccoons in our study selected the largest cavity trees as den trees, most of which were American beech, a species that is cavity-prone on many hardwood sites [50,54]. Reference [10] reported an even greater bias (91\%) towards American beech as a den tree.

The relative importance of den sites, food, or other resources as priorities influencing raccoon habitat selection varies among seasons and age and sex groups [18]. Some raccoons apparently are more flexible and can adapt to varying circumstances. Reference [55] reported raccoons will travel relatively long distances between concentrated food resources and daytime den sites. However, the scale (temporal or spatial) at which resources are distributed influences the process of habitat selection, with selection of food resources typically occurring at fine spatial scales and landscape structure and patterns at broader scales influencing selection of macrohabitats comprising home ranges [45]. Most raccoons in our study area reduced their use of tree cavities and chose to use nearby burrows when responding to highly desirable ephemeral food resources [18]. For females with young, however, the availability of nearby cavities for denning may be crucial for successful reproduction with consequences for the entire population.

Landscape heterogeneity influences the extent to which desirable fine-scale resources and preferred macrohabitats occur coincidentally and thus ultimately determines whether individuals must make trade-offs when selecting resources [45]. Broad-scale disturbances contribute to landscape heterogeneity by modifying the species composition and structural characteristics of vegetation communities within and among habitat types [26]. Although many hardwood forests in the southeastern United States are managed to achieve wildlife habitat restoration, this may require complete removal of the existing canopy on previously logged forests (especially on public lands). Our results suggest that removal of large-diameter stems across large areas could impact arboreal species or other wildlife that depend on cavities for denning. To ensure that wildlife populations that depend on cavities or other attributes of large deciduous trees are not locally extirpated, we encourage managers to consider retaining large-diameter stems within or near harvested sites (e.g., streamside management zones or other unharvested areas).

\section{Conclusions}

Resource selection by raccoons can be significantly influenced by several proximate factors. Moreover, inferences regarding selection of resources may vary, and even appear conflicting, when examined at different spatial scales and preferred resources are spatially segregated. Sorting out meaningful and useful generalizations becomes even more difficult when individuals within populations exhibit different priorities in selecting resources. We caution generalizing specific values or differences reported in this study because of the small number of raccoons represented in some analyses. Still, the significant differences and patterns we report likely indicate meaningful biological variation that warrants some consideration in land-use or conservation planning.

An additional contribution of our findings is recognition that all raccoons are not identical in their immediate needs or behaviors related to resource selection and significant components of that dissimilarity are seasonal and attributable to age and sex of individuals. What most raccoons choose to do most of the time in different ecological circumstances may not be as important in considering management options as whether crucial resources are coincidentally available to a relatively few individuals during a narrow window of time to facilitate successful reproduction. Thus, the question posed by the title of this paper identifies a key challenge facing land managers today and in the future. That is, how do we manage hardwood forests so that habitat use is not a compromise in selection of fine-scale resources because of constraints imposed by landscape configurations?

\section{Acknowledgements}

We thank the Tennessee Wildlife Resources Agency and Tech Aqua, College of Arts and Sciences, Tennessee Technological University for supporting this study. J. M. Benner, D. L Borden, and J. H. McGuiness helped with various aspects of the study. Beverly Collins reviewed an early draft of this manuscript and provided valuable comments.

\section{REFERENCES}

[1] J. H. Kaufmann, "Raccoons and Allies," In: J. A. Chapman and G. A. Feldhammer, Eds., Wild Mammals of North America: Biology, Management and Economics, 
John Hopkins University Press, Baltimore, 1982, pp. 567585 .

[2] S. S. Ditchkoff, S. T. Saalfeld and C. J. Gibson, "Animal Behavior in Urban Ecosystems: Modifications Due to Human-Induced Stress," Urban Ecosystems, Vol. 9, No. 1, 2006, pp. 5-12. doi:10.1007/s11252-006-3262-3

[3] K. M. Hodges, M. J. Chamberlain and B. D. Leopold, "Effects of Summer Hunting on Ranging Behavior of Adult Raccoons in Central Mississippi," Journal of Wildlife Management, Vol. 64, No. 1, 2000, pp. 194-198. doi: $10.2307 / 3802990$

[4] R. J. Greenwood, "Foods of Prairie Raccoons during the Waterfowl Nesting Season," Journal of Wildlife Management, Vol. 45, No. 3, 1981, pp. 754-760. doi: $10.2307 / 3808714$

[5] F. W. Stuewer, "Raccoons: Their Habits and Management in Michigan," Ecological Monographs, Vol. 13, No. 2, 1943, pp. 203-257. doi:10.2307/1943528

[6] J. L. Cabalka, R. R. Costa and G. O. Hendrickson, "Ecology of the Raccoon in Central Iowa," Proceedings of Iowa Academy of Science, Vol. 60, 1953, pp. 616-620.

[7] R. S. Dorney, "Ecology of Marsh Raccoons," Journal of Wildlife Management, Vol. 18, No. 2, 1954, pp. 217-225. doi: $10.2307 / 3797717$

[8] L. W. Giles, "Utilization of Rock Exposures for Dens and Escape Cover by Raccoons," American Midland Naturalist, Vol. 27, No. 1, 1942, pp. 171-176. doi: $10.2307 / 2421032$

[9] R. T. Butterfield, "Populations, Hunting Pressure, and Movements of Ohio Raccoons," Transactions of the North American Wildlife and Natural Resource Conference, Vol. 21, No. 9, 1944, pp. 344-397.

[10] R. T. Butterfield, "The Buying of Den Trees for Raccoon Management," Journal of Wildlife Management, Vol. 14, No. 2, 1950, pp. 244-246. doi:10.2307/3796344

[11] L. F. Whitney and A. B. Underwood, "The Raccoon," Practical Science Publication Company, Orange, 1952.

[12] H. J. Stains, "The Raccoon in Kansas-Natural History, Management, and Economic Importance," University of Kansas Museum of Natural History State Biological Survey Miscellaneous Publications, Vol. 10, 1956, pp. 1-76.

[13] L. D. Mech, J. R. Tester and D. W. Warner, "Fall Day Time Resting Habits of Raccoons as Determined by Telemetry," Journal of Mammalogy, Vol. 47, No. 3, 1966, pp. 450-466. doi:10.2307/1377686

[14] G. H. Hardy, "Movement Ecology of Resident Raccoons in East Tennessee," M.S. Thesis, University of Tennessee, Knoxville, 1979.

[15] C. I. Taylor, "Movements, Activities and Survival of Translocated Raccoons in East Tennessee," M.S. Thesis, University of Tennessee, Knoxville, 1979.

[16] A. R. Rabinowitz and R. Pelton, "Day-Bed Use by Raccoons," Journal of Mammalogy, Vol. 67, No. 4, 1986, pp. 766-769. doi: $10.2307 / 1381145$

[17] J. R. Robb, M. S. Cramer, A. R. Parker and R. P. Urbanek, "Use of Tree Cavities by Fox Squirrels and Raccoons in
Indiana," Journal of Mammalogy, Vol. 77, No. 4, 1996, pp. 1014-1027. doi:10.2307/1382782

[18] K. M. Endres and W. P. Smith, "Influence of Age, Sex, Season and Availability on Den Selection by Raccoons within the Central Basin of Tennessee," American Midland Naturalist, Vol. 129, No. 1, 1993, pp. 116-131. doi: $10.2307 / 2426440$

[19] N. A. Preble, "The Status and Management of Raccoon in Central Ohio," M.S. Thesis, Ohio State University, Columbus, 1940.

[20] A. Berner and L. W. Gysel, "Raccoon Use of Large Tree Cavities and Ground Burrows," Journal of Wildlife Management, Vol. 31, No. 4, 1967, pp. 706-714. doi: $10.2307 / 3797973$

[21] J. H. Schnell, "Rest Site Selection by Radio-Tagged Raccoons," Minnesota Academy of Science, Vol. 36, 1970, pp. 83-88.

[22] D. G. Schneider, L. D. Mech and J. R. Tester, "Movements of Female Raccoons and Their Young as Determined by Radio-Tracking," Animal Behavior Monograph, Vol. 44, Part 1, 1971, pp. 1-43.

[23] W. P. Smith, D. L. Borden and K. M. Endres, "ScentStation Visits as an Index to Raccoon Abundance: An Experimental Manipulation," Journal of Mammalogy, Vol. 75, No. 3, 1994, pp. 637-647. doi:10.2307/1382511

[24] W. C. Moffitt, J. F. Brasfield, J. F. Campbell and R. K. Moore, "Soil Survey of DeKalb County, Tennessee," United States Department of Agriculture, Soil Conservation Service, Washington DC, 1972.

[25] E. L. Braun, "Deciduous Forests of Eastern North America," McGraw-Hill Book Company, New York, 1950.

[26] S. M. Stubblefield Jr., "Soil-Water Relationships of the Vascular Flora of Davies Island, Center Hill Reservoir, DeKalb, County, Tennessee," M.S. Thesis, Tennessee Technological University, Cookeville, 1968.

[27] T. M. Schuler, "Fifty Years of Partial Harvesting in a Mixed Mesophytic Forest: Composition and Productivity," Canadian Journal Forestry Research, Vol. 34, No. 5, 2004, pp. 985-997. doi:10.1139/x03-262

[28] K. M. Endres, "Behavior and Ecology of an Island Population of Raccoons (Procyon lotor) within the Central Basin, Tennessee," M.S. Thesis, Tennessee Technological University, Cookeville, 1989.

[29] W. J. Bigler and G. L. Hoff, "Anesthesia of Raccoons with Ketamine Hydrochloride," Journal of Wildlife Management, Vol. 38, No. 2, 1973, pp. 364-367. doi: $10.2307 / 3800748$

[30] D. A. Gregg and L. D. Olson, "The Use of Ketamine Hydrochloride as an Anesthetic for Raccoons," Journal of Wildlife Disease, Vol. 11, No. 3, 1975, pp. 335-337.

[31] G. A. Grau, G. C. Sanderson and J. P. Rogers, "Age Determination of Raccoons," Journal of Wildlife Management, Vol. 34, No. 2, 1970, pp. 364-372. doi: $10.2307 / 3799023$

[32] G. C. Sanderson, "Methods of Measuring Productivity in Raccoons," Journal of Wildlife Management, Vol. 14, No. 
Tree Attributes and Availability or Landscape Heterogeneity?

\section{4, 1950, pp. 389-402. doi:10.2307/3797269}

[33] J. R. Alldredge and J. T. Ratti, "Further Comparison of Some Statistical Techniques for Analysis of Resource Selection," Journal of Wildlife Management, Vol. 56, No. 1, 1992, pp. 1-9. doi: $10.2307 / 3808785$

[34] W. P. Smith, "Plant Associations within the Interior Valleys of the Umpqua River Basin, Oregon," Journal of Range Management, Vol. 38, No. 6, 1985, pp. 526-530. doi:10.2307/3899745

[35] G. Cottam and J. T. Curtis, "The Use of Distance Measures in Phytosociological Sampling," Ecology, Vol. 37, No. 3, 1956, pp. 451-460. doi:10.2307/1930167

[36] SAS Institute, Inc., "SAS/STAT User's Guide, Release 6.03 Edition," SAS Institute, Inc. Cary, 1988.

[37] J. H. Zar, "Biostatistical Analysis," 4th Edition, Prentice-Hall, Inc., Englewood Cliffs, 1999.

[38] R. I. Jennrich and F. B. Turner, "Measurement of NonCircular Home Range," Journal of Theoretical Biology, Vol. 22, No. 2, 1969, pp. 227-237. doi:10.1016/0022-5193(69)90002-2

[39] C. W. Neu, C. R. Byers and J. M. Peck, “A Technique for Analysis of Utilizati6n-Availability Data," Journal of Wildlife Management, Vol. 38, No. 3, 1974, pp. 541-545. doi: $10.2307 / 3800887$

[40] W. P. Smith, "A Bivariate Normal Test for Elliptical Home-Range Models: Biological Implications and Recommendations," Journal of Wildlife Management, Vol. 47, No. 3, 1983, pp. 613-619. doi:10.2307/3808599

[41] W. P. Smith and B. E. Coblentz, "Cattle or Sheep Reduce Fawning Habitat Available to Columbian White-Tailed Deer in Western Oregon," Northwest Science, Vol. 84, No. 3, 2010, pp. 315-326. doi:10.3955/046.084.0401

[42] N. J. Aebischer, P. A. Robertson and R. E. Kenward, "Compositional Analysis of Habitat Use from Animal Radio-Tracking Data," Ecology, Vol. 74, No. 7, 1993, pp. 1313-1325. doi: $10.2307 / 1940062$

[43] D. H. Johnson, "The Comparison of Usage and Availability Measurements for Evaluating Resource Preference," Ecology, Vol. 61, No. 1, 1980, pp. 65-71. doi: $10.2307 / 1937156$

[44] J. H. Pedlar, L. Fahrig and H. G. Merriam, "Raccoon Habitat Use at 2 Spatial Scales," Journal of Wildlife
Management, Vol. 61, No. 1, 1997, pp. 102-112. doi: $10.2307 / 3802419$

[45] M. S. Boyce, "Scale for Resource Selection Functions," Diversity and Distribution, Vol. 12, No. 3, 2006, pp. 269 276. doi:10.1111/j.1366-9516.2006.00243.x

[46] A. S. Johnson, "Biology of the Raccoon (Procyon lotor varius Nelson and Goldman) in Alabama," Agricultural Experiment Station. Bulletin. No. 402. Auburn University, 1970.

[47] E. K. Fritzell, "Aspects of Raccoon (Procyon lotor) Social Organization," Canadian Journal of Zoology, Vol. 56, No. 2, 1978, pp. 260-271. doi:10.1139/z78-035

[48] D. W. Allsbrooks and M. L. Kennedy, "Movement Patterns of Raccoons (Procyon lotor) in Western Tennessee," Journal of the Tennessee Academy of Science, Vol. 62, No. 1, 1987, pp. 15-19.

[49] F. R. Tabatabai, "Ecology of the Raccoon (Procyon lotor) in Tennessee," Ph.D. Thesis, Memphis State University, Memphis, 1988.

[50] C. M. Nixon, S. P. Havera and L. P. Hansen, "Initial Response of Squirrels to Forest Changes Associated with Selection Cutting," Wildlife Society Bulletin, Vol. 8, No. 4, 1980, pp. 298-305.

[51] P. D. Goodrum, V. H. Reid and C. E. Boyd, "Acorn Yields, Characteristics, and Management Criteria of Oaks for Wildlife," Journal of Wildlife Management, Vol. 35, No. 3, 1971, pp. 520-532. doi:10.2307/3799707

[52] A. W. Allen and J. G. Corn, "Relationships between Live Tree Diameter and Cavity Abundance in a Missouri Oak-Hickory Forest," Northern Journal of Applied Forestry, Vol. 7, No. 4, 1990, pp. 179-183.

[53] W. C. McComb, "Forestry and Wildlife Habitat Management in Central Hardwoods," Journal of Forestry, Vol. 80, No. 8, 1982, pp. 490-492.

[54] M. S. Lowney and E. D. Hill, "Wood Duck Nest Sites in Bottomland Hardwood Forests of Mississippi," Journal of Wildlife Management, Vol. 53, No. 2, 1989, pp. 378-382. doi: $10.2307 / 3801140$

[55] L. W. van Druff, "The Ecology of the Raccoon and Opossum, with Emphasis on Their Role as Waterfowl Nest Predators," Ph.D. Thesis, Cornell University, Ithaca, 1971. 